\title{
INVENTARISASI TUMBUHAN BERKHASIAT OBAT DI SEKITAR PEKARANGAN DI KELURAHAN SENTOSA
}

\author{
Ajeng Larassati ${ }^{1}$, Marmaini ${ }^{2}$, Trimin Kartika ${ }^{3}$ \\ Program Studi Biologi, Fakultas Matematika dan Ilmu Pengetahuan Alam \\ Universitas PGRI Palembang \\ *e-mail: triminkartika1969@gmail.com
}

\begin{abstract}
Research on Inventory of Medicinal Herbs Around the Yard in Sentosa Village was conducted in March to April 2019 in Sentosa Village, Seberang Ulu II District, Plaju Palembang. The research aims to find out the types of medicinal plants around the yard, parts of plants used as medicine, and types of diseases that can be treated. The study uses descriptive survey methods and observation methods of interviews with local communities. The results of the study are based on the data obtained that medicinal plants in the yard of Sentosa Subdistrict, Seberang Ulu 2 District of Palembang from the Spermatopyta division consist of 2 classes, 13 families, 14 orders, 20 genera and 20 species of medicinal plants. Plant parts which are used as medicine from the monocotyledon class are rhizomes, roots and leaves because the rhizomes have active compounds, flavonoids, saponins, and essential oils, while the dicotyledone class part that is widely used as medicine is leaves, because many leaves contain compounds such as tannins, alkaloids, essential oils that are useful as drugs stored in the tissues of the leaves. Utilization of the most efficacious medicinal plant parts the highest percentage of leaves in $80 \%$, while in the roots of $45 \%$.
\end{abstract}

Keywords: Inventory, house yard, medicinal plants.

\begin{abstract}
ABSTRAK
Penelitian tentang Inventarisasi Tumbuhan Berkhasiat Obat Di Sekitar Pekarangan di Kelurahan Sentosa telah dilakukan pada Maret sampai April 2019 di Kelurahan Sentosa Kecamatan Seberang Ulu II Plaju Palembang. Penelitian bertujuan untuk mengetahui jenis - jenis Tumbuhan Berkhasiat Obat di sekitar pekarangan, bagian tumbuhan yang dimanfaatkan sebagai obat, dan jenis penyakit yang dapat diobat. Penelitian menggunakan metode survey deskriptif dan metode observasi wawancara dengan masyarakat setempat. Hasil penelitian berdasarkan data yang didapatkan bahwa tanaman yang berkhasiat obat dipekarangan Kelurahan Sentosa Kecamatan Seberang Ulu 2 Palembang dari divisio Spermatopyta terdiri dari 2 class, 13 familia, 14 ordo, 20 genus dan 20 spesies tumbuhan berkhasiat obat. Bagian-bagian tanaman yang digunakan sebagai obat dari kelas monokotil adalah rimpang, akar dan daun karena rimpang memiliki senyawa aktif, flavonoid, saponin, dan minyak atsiri, sedangkan kelas dikotiledone bagian yang banyak digunakan sebagai obat adalah daun, karena pada daun banyak mengandung senyawa seperti tannin, alkaloid, minyak atsiri yang berguna sebagai obat yang tersimpan di jaringan pada daun. Pemanfaatan bagian tumbuhan berkhasiat obat persentasi tertinggi pada daun sebesar $80 \%$, sedangkan pada akar sebesar $45 \%$.
\end{abstract}

Kata Kunci: Inventarisasi, pekarangan rumah, tumbuhan berkhasiat obat. 


\section{PENDAHULUAN}

Sejak dahulu bangsa Indonesia telah mengenal dan memanfaatkan tumbuhan berkhasiat obat sebagai salah satu upaya untuk menanggulangi masalah kesehatan, jauh sebelum pelayanan kesehatan formal dengan obatobatan modern yang dikenal masyarakat. Tradisi penggunaan obat tradisional diturunkan dari satu generasi ke generasi dan telah berlangsung dalam kurun waktu yang lama. Bermula dari hasil uji coba masyarakat terhadap tumbuhtumbuhan yang ada disekitar tempat hidup mereka untuk memenuhi kebutuhan akan pengobatan (Rahim et al. 2013). Tumbuhan merupakan keanekaragaman hayati yang menjadikan Indonesia memiliki kekayaan alam terbesar urutan kedua di dunia. Indonesia memiliki sekitar 90.000 spesies tumbuhan, dimana 9.600 diketahui berkhasiat sebagai obat dan 300 spesies telah digunakan sebagai bahan obat tradisional oleh industri obat tradisional (Permenkes RI, 2013).

Tumbuhan merupakan sumber dari obat-obatan yang digunakan dalam pengobatan berbagai penyakit. Secara historis semua persiapan obat yang berasal dari tanaman, baik dalam bentuk sederhana dari bagian tanaman atau dalam bentuk yang lebih kompleks dari ekstrak mentah, campuran, dan lain sebagainya. Saat ini sejumlah besar obat yang dikembangkan dari tanaman yang aktif melawan sejumlah sejumlah penyakit (Shosan, 2014).

Masyarakat secara turuntenurun telah lama mengenal fungsi tumbuhan sebagai obat tradisional dalam upaua mengatasi masalah kesehatan. Tumbuhan obat adalah tumbuhan yang memiliki berkhasiat obat dan digunakan sebagai pengobatan dalam penyembuhan maupun pencegahan penyakit. Pengertian yang dimaksud berkhasiat obat adalah mengandung zat aktif yang berfungsi mengobati penyakit tertentu.

Tumbuhan obat adalah seluruh spesies tumbuhan yang diketahui atau dipercaya mempunyai khasiat obat. Tumbuhan obat tersebut dikelompokkan menjadi : 1) tumbuhan obat tradisional, 2) tumbuhan obat modern, dan 3) tumbuhan obat potensial. Tumbuhan obat tradisional adalah spesies tumbuhan yang diketahui atau dipercayai masyarakat mempunyai khasiat obat dan telah digunakan sebagai bahan baku obat tradisional. Tumbuhan obat modern adalah spesies tumbuhan obat yang secara ilmiah telah dibuktikan mengandung senyawa/bahan bioaktif yang berkhasiat obat dan penggunaannya dipertanggungjawabkan secara medis. Tumbuhan obat potensial adalah tumbuhan obat yang mengandung senyawa atau bahan aktif yang berkhasiat obat (Rubiah et al.2015).

Tumbuhan obat tidak berarti tumbuhan yang ditanam sebagai tanaman obat.Tanaman obat yang tergolong rempah-rempah atau bumbu dapur, tanaman pagar, tanaman buah, tanaman sayur atau bahkan tanaman liar juga dapat digunakan sebagai tanaman yang di manfaatkan untuk mengobati berbagai macam penyakit. Banyak obat-obatan modern yang terbuat dari tanaman obat, hanya saja peracikannya dilakukan secara klinis dilaboratorium sehingga terkesan modern. Penemuan kedokteran modern juga dapat mendukung penggunaan obat- obatan tradisional (Hariana, 2008).

Tanaman obat diartikan sebagai jenis tanaman yang sebagian atau seluruh tanaman yang digunakan sebagai obat dan ramuan obat-obatan. Tumbuhan berkhasiat obat mengandung eksudat, ialah isi sel yang secara spontan keluar dari tanaman atau dengan cara tertentu sengaja dikeluarkan dari selnya dan belum berupa zat kimia atau zat murni 
yang dapat berkhasiat obat (Herdiani, 2012).

Indonesia merupakan negara yang sebagian besar menggunakan tanaman obat sebagai pengobatan tradisional dan telah digunakan oleh masyarakat sejak seratus tahun yang lalu. Pengalaman nenek moyang kita dalam meramu tanaman untuk pengobatan tradisional telah diwariskan dari generasi ke generasi. Penggunaan tanaman secara tradisional untuk pengobatan di Indonesia sejak zaman dahulu. Seni dan pengetahuan penggunaan tanaman sebagai obat diturunkan secara lisan dari generasi kegenerasi. Beberapa tanaman yang masih digunakan dalam pengobatan tradisional dapat ditemukan pada dinding- dinding Candi di Jawa seperti Borobudur, Prambanan, Penataran, dan Sukuh (Gailea, 2004).

Tumbuhan berkhasiat obat merupakan tumbuhan yang pada bagianbagian tertentu baik akar, batang, daun, buah maupun hasil ekskresinya dipercaya dapat menyembuhkan atau mengurangi rasa sakit. Saat ini, upaya pengobatan dengan bahan-bahan alam berkembang pesat. Perkembangan pemanfaatan tumbuhan obat sangat prospektif ditinjau dari berbagai faktor pendukung, seperti tersedianya sumber daya hayati yang kaya dan beranekaragam di Indonesia (Falah et al. 2013).

Pemanfaatan sumber daya alam yang berpotensi sebagai obat dapat bermula dari pekarangan rumah masyarakat di lingkungan tempat tinggal pedesaan. Oleh karena itu di lingkungan tersebut banyak masyarakat yang menanam tanaman obat sebagai pencegahan atau pengobatan pertama bagi keluarga mereka terhadap suatu penyakit.

Dengan adanya pemahaman yang benar berkenaan dengan pengobatan herbal, masyarakat akan terdorong untuk menanam tanaman obat lebih banyak sehingga pemanfaatannya pun akan lebih banyak pula.(Sopian et al .2013).

Masyarakat kelurahan Sentosa Kecamatan Seberang Ulu II Palembang telah memanfaatkan tumbuhan sebagai obat tradisional. Penduduk tersebut meyakini bahwa tanaman obat dapat mencegah dan menyembuhkan berbagai jenis penyakit. Pengetahuan tumbuhan yang dapat digunakan sebagai pengobatan tradisional mereka dapatkan secara turun- temurun. Penduduk kelurahan Sentosa Kecamatan Seberang Ulu 2 Palembang tersebut banyak menggunakan tanaman dalam pengobatan tradisional. Pemanfaatan tumbuhan obat umumnya dipercayakan kepada para orang-orang tua yang berada di Kecamatan tersebut untuk membantu mereka dalam pengobatan tradisional.

Berdasarkan hasil observasi dan wawancara pada masyarakat kelurahan Sentosa Kecamatan Seberang Ulu 2 Palembang, tumbuhan obat masih dianggap berperan penting memanfaatkan beberapa tumbuhan tertentu untuk mengobati penyakit, salah satunya dengan memanfaatkan tumbuhan sirih (Piper betle L.) untuk obat mimisan, batuk dan bau mulut. Oleh karena itu perlu dilakukan inventarisasi tumbuhan berkhasiat obat

dikawasan ini. Hal ini penting dilakukan untuk mengetahui keberadaannya dan upaya pemanfaatnya.

\section{BAHAN DAN METODE}

Penelitian ini dilaksanakan di Kelurahan Sentosa Kecamatan Seberang Ulu 2 Plaju Palembang. Waktu penelitian selama 2 bulan dimulai dari bulan Maret sampai bulan April 2019. Data diidentifikasi di Laboratorium Biologi Universitas PGRI Palembang. Alat yang digunakan adalah alat tulis, kamera digital, kertas karton, alkohol, gunting dan isolasi. Bahan yang digunakan adalah spesimen tumbuhan berkhasiat 
obat yang terdapat di pekarangan rumah masyarakat Kelurahan Sentosa Kecamatan Seberang Ulu 2 Plaju Palembang.

Metode yang digunakan dalam penelitian ini adalah metode survey deskriptif yaitu metode observasi lansung. Pengumpulan data dilakukan berdasarkan hasil wawancara dengan responden secara semi terstruktur dan hasil wawancara. Sampel yang didapat secara deskriptif untuk mengetahui jenisjenis tumbuhan khasiat tumbuhan obat yang digunakan masyarakat Kelurahan Sentosa. Hasil wawancara dan spesimen yang telah didapat dianalisis secara deskriptif untuk mengetahui jenis-jenis tanaman obat, bagian tanaman yang dimanfaatkan sebagai obat, dan jenis penyakit yang diobati dengan tujuan inventarisasi dan indentifikasi.

Hasil wawancara dan spesimen yang telah didapat dianalisis secara deskriptif untuk mengetahui jenis-jenis tanaman obat, bagian tanaman yang dimanfaatkan sebagai obat, dan jenis penyakit yang diobati dengan tujuan inventarisasi dan indentifikasi.

Identifikasi tumbuhan berkhasiat obat selain informasi dari masyarakat juga menggunakan literatur tentang khasiat tanaman obat yaitu Azzymi (2016), Kartika 2017). Hasil yang didapatkan kemudian dianalisis menggunakan analisis deskriptif.

\section{HASIL DAN PEMBAHASAN}

Dari hasil penelitian yang telah dilakukan diKelurahan Sentosa Kecamatan Seberangan Ulu 2 ditemukan dari divisio Spermatopyta terdiri dari , 12 ordo, 13 familia, 2 class, 20 genus dan 20 spesies pada tabel 3 . di bawah ini:

Tabel 1. Jenis-jenis Tumbuhan Berkhasiat obat di Pekarangan Kelurahan Sentosa Kecamatan seberang Ulu 2 Palembang.

\begin{tabular}{|c|c|c|c|c|c|c|}
\hline No & Kelas & Ordo & Familia & Genus & Spesies & $\begin{array}{c}\text { Nama } \\
\text { Lokal }\end{array}$ \\
\hline 1 & Monocotyledon & Asparagales & Ruscaceae & Dracaena & Dracaena angustifolia & Suji \\
\hline 2 & & Zingiberales & Zingiberaceae & Kaempferia & Kaempferia galanga & Kencur \\
\hline 3 & & & & Zingiber & Zingiber casumounar & Bangle \\
\hline 4 & & & & Curcuma & Curcuma longa & Kunyit \\
\hline 5 & & & & Eleutherine & Eleutherine palmifolia $\mathrm{L}$ & Bawang Dayak \\
\hline 6 & Dicotyledon & Asterales & Asteraceae & Pluchea & Pluchea indica L. & Beluntas \\
\hline 7 & & & & Cosmos & Cosmos caudatus & Kenikir \\
\hline 8 & & & Campanulaceae & Isotoma & Isotoma longiflora & Daun Katarak \\
\hline 9 & & Rubiales & Rubiaceae & Gardenia & Gardenia augusta & Kaca Piring \\
\hline 10 & & Lamiales & Lamiaceae & Morinda & Morinda citrifolia $\mathrm{L}$. & Mengkudu \\
\hline 11 & & & & Ocimum & Ocimum citriodorum & Kemangi \\
\hline 12 & & & & Coleus & Coleus atropurpureus & Ati Ati \\
\hline 13 & & & & Orthosiphon & Orthosiphon aristatus & Kumis Kucing \\
\hline 14 & & Fabales & Caesal piniaceae & Saraca & Saraca indica & Bunga Asoka \\
\hline 15 & & Rosales & Rhamnaceae & Ziziphus & Ziziphus uritiana & Bidara \\
\hline 16 & & Malpighiales & Euphorbiaceae & Euphorbia & Euphorbia milli & Euphorbia \\
\hline 17 & & Piperales & Piperaceae & Peperomia & Peperomia pellucida & Tumpangan Air \\
\hline 18 & & & & Piper & Piper betle L. & Sirih \\
\hline 19 & & Caryophyllales & Amaranthaceae & Amaranthus & Amaranthus spinosus & Bayam Duri \\
\hline 20 & & Solanaceae & Acanthaceae & Andrographis & Andrographis paniculata & Sambiloto \\
\hline
\end{tabular}

$\begin{array}{lccl}\text { Berdasarkan } & \text { Tabel 1. Divisio } & & \text { Dari class monocotile ditemukan 5 } \\ \text { Spermathophyta } & \text { dari } & \text { class } & \text { spesies yaitu Dracaena angustifolia, } \\ \text { monocotyledon dan class dicotiledone. } & \text { Kaempferia } & \text { galangal, }\end{array}$


casumounar, Curcuma longa, Eleutherine palmifolia L. Tumbuhan ini ditemukan di pekarangan sekitar rumah masyarakat, dan tumbuh di daerah dataran rendah atau pegunungan yang tanahnya gembur dan tidak terlalu banyak air. Tumbuhan dari spesies ini mengandung minyak atsiri dan alkaloid yang dimanfaatkan sebagai stimulan.

Class Dicotiledone ditemukan 15 spesies yaitu Pluchea indica L., Cosmos caudatus, Isotoma longiflora, Gardenia augusta, Morinda citrifolia L., Ocimum citriodorum, Coleus atropurpureus, Orthosiphon aristatus, Saraca indica, Ziziphus mauritiana, Euphorbia milli,
Peperomia pellucid, Piper betle L., Amaranthus spinosus, Andrographis paniculata. Spesies ini dapat ditemukan dipekarangan rumah, di perkebunan, dan di hutan.

Dari tabel 1. Jenis-jenis tumbuhan berkhasiat obat yang terinventarisasi oleh masyarakat Kelurahan Sentosa ada yang sudah diketahui dan ada yang belum diketahui pemanfaatannya. Pada tabel 2. Menjelaskan bagian tanaman dari class Monocotiledon yang digunakan sebagai obat dan jenis penyakit yang diobati sebagai berikut.

Tabel 2. Bagian Tumbuhan yang dimanfaatkan sebagai obat Masyarakat Kelurahan Sentosa Kecamatan Seberang Ulu 2 Palembang Class Monocotiledone.

\begin{tabular}{|l|l|r|l|}
\hline No & \multicolumn{1}{|c|}{ Nama Spesies } & $\begin{array}{c}\text { Bagian yang } \\
\text { Digunakan }\end{array}$ & \multicolumn{1}{|c|}{ Khasiat Tumbuhan } \\
\hline 1. & Dracaena angustifolia & Daun, akar & $\begin{array}{l}\text { Menurunkan kolesterol, mengobatan } \\
\text { leukimia, gondok, keputihan, mengatasi } \\
\text { asma dan gangguan pernapasan, } \\
\text { meningkatkan produk ASI, mengatasi } \\
\text { disentri, meredakan rasa nyeri haid. }\end{array}$ \\
\hline 2. & Kaempferia galanga & $\begin{array}{c}\text { Daun, } \\
\text { rimpang }\end{array}$ & $\begin{array}{l}\text { Menambah nafsu makan, mengobati batuk, } \\
\text { menghilangkan stres, mengobati diare, } \\
\text { masuk angin, dan mengobati keseleo. }\end{array}$ \\
\hline 3. & Zingiber casumounar & Batang, & $\begin{array}{l}\text { Untuk mengobati cacingan, masuk angin, } \\
\text { demam, nyeri sendi, obat sakit kuning. }\end{array}$ \\
\hline 4. & Eleutherine palmifolia L & Rimpang & $\begin{array}{l}\text { Mengobati sembelit, kanker payudara, } \\
\text { diabetes, meningkatkan sistem imun, } \\
\text { mengobati penyakit jantung, penyakit } \\
\text { kuning, hipertensi. }\end{array}$ \\
\hline 5. & Pluchea indica L. & Daun, akar & $\begin{array}{l}\text { Meningkatkan nasu makan, melancarkan } \\
\text { pencernaan, meredakan demam, } \\
\text { menghilangkan bau badan dan bau mulut, } \\
\text { meluruhkan keringat, meredakan } \\
\text { nyeritulang dan sendi. }\end{array}$ \\
\hline
\end{tabular}


Spesies tumbuhan obat dari class Monocotiledone yang diketahui di pekarangan rumah masyarakat Kelurahan Sentosa Kecamatan Seberang Ulu 2 Palembang dengan kegunaan yang berbeda-beda, spesies tumbuhan obat yang berhasil teridentifikasi sebanyak 5 spesies. Pada class Monocotiledone ini bagian tumbuhan yang banyak digunakan sebagai obat adalah rimpang seperti umbi/akar dan daun. Tanaman berakar rimpang memiliki senyawa aktif, flavonoid, saponin, dan minyak atsiri yang dapat digunakan sebagai obat, beberapa khasiat rimpang berhubungan dengan pencernaan dan penggunaannya dengan cara meminum ekstrak rimpang, dan rebusan daun.

Pengobatan yang dilakukan dengan cara tradisional oleh masyarakat berkhasiat menurunkan kolesterol, mengobatan leukimia, gondok, keputihan, mengatasi asma dan gangguan pernapasan, meningkatkan produk ASI, mengatasi disentri, meredakan rasa nyeri haid, menambah nampu makan, mengobati penyakit jantung, penyakit kuning, hipertensi, menghilangkan bau badan, meredahkan nyeri tulang dan sendi, dan lain sebagainya.

Daun suji yang memiliki kandungan antioksidan yang tinggi, karena banyaknya klorofil pada tumbuhan tersebut. Tanaman Suji dimanfaatkan untuk menaikkan nilai ekonomi dari daun suji. Daun dimanfaatkan sebagai pewarna alami dalam skala tradisional dan belum dimanfaatkan secara komersial (Prangdimurti, et al . 2006). Potensi daun suji sebagai salah satu sumber warna hijau sangat besar digunakan sebagai bahan pewarna hijau pada produk pangan ataupun minuman.

Kunyit (Curcuma domestica L) dapat mengobati diabetes melitus, tipes, usus, buntu, sakit keputihan, sakit perut dan mules sat sedang datang haid, memperlancar haid dan asi pada ibu menyusui, menambah nafsu makan, diare dan kanker. Menurut Dalimartha (2009). Kunyit mempunyai rasa rimpang agak pahit, sedikit pedas, hangat, tidak beracun, astrigen, dan berbau aromatik.

Secara empirik kencur digunakan sebagai penambah nafsu makan, ekspektoran, obat batuk, disentri, tonikum, infeksi bakteri, masuk angin, dan sakit perut (Rostiana, et al. 2007). Menurut Rahayu (2002), rimpang kencur mengandung saponin, flavonoida dan senyawa-senyawa polifenol, di samping minyak atsiri $(2,4-3,9 \%)$ yang mengandung sineol, borneol, kamfer, etil alkohol, asam metilkaneelat dan senyawa-senyawa pentadekan.

Bawang dayak diketahui
memiliki kandungan fitokimia
seperti alkaloid, flavanoid, steroid,
glikosida, fenolik dan zat tanin yang
semuanya berperan besar terhadap
kesehatan. Ry Galingging (2009),
menyebutkan bahwa kandungan
kimia bawang dayak dapat bersifat
antikanker, antiinflamasi, antibakteri
dan antioksid.

Bawang dayak diketahui memiliki kandungan fitokimia seperti alkaloid, flavanoid, steroid, glikosida, fenolik dan zat tanin yang semuanya berperan besar terhadap kesehatan. Ry Galingging (2009), menyebutkan bahwa kandungan kimia bawang dayak dapat bersifat dan antioksid. 
Tabel 3. Bagian Tumbuhan yang dimanfaatkan sebagai obat Masyarakat Kelurahan Sentosa Kecamatan Seberang Ulu 2 Palembang Class Dicotiledone.

\begin{tabular}{|c|c|c|c|}
\hline No & Nama Spesies & \begin{tabular}{|c|} 
Bagian yang \\
Digunakan
\end{tabular} & Khasiat Tumbuhan \\
\hline 1. & Cosmos caudatus & $\begin{array}{l}\text { Seluruh } \\
\text { bagian }\end{array}$ & $\begin{array}{l}\text { Meningkatkan nafsu makan, } \\
\text { mengatasi bau mulut, meningkatkan } \\
\text { sistem kekebalan tubuh, } \\
\text { menguatkan kerangka tulang, organ } \\
\text { jantung, mengobati penyakit } \\
\text { gondongan, membersihkan darah } \\
\text { dari racun }\end{array}$ \\
\hline 2. & Isotoma longiflora & Daun, bunga & $\begin{array}{l}\text { Menyembuhkankatarak, mengobati } \\
\text { sakit mata, mata katarak, } \\
\text { menyembuhkan asma dan radang } \\
\text { tenggorokan, menyembuhkan } \\
\text { kanker }\end{array}$ \\
\hline 3. & Gardenia al & Dau & $\begin{array}{llrr}\text { Mengobati sariawan, } & \text { sakit } & \text { gigi, } \\
\text { demam, gangguan } & \text { liver, } & \text { dan } \\
\text { mengobati diabetes } & & \end{array}$ \\
\hline 4. & $\begin{array}{l}\text { Morinda citrifolia } \\
\text { L. }\end{array}$ & $\begin{array}{l}\text { Daun, } \\
\text { getah, biji, } \\
\text { akar, buah }\end{array}$ & $\begin{array}{l}\text { Batuk, disentri, radang usus, pelancar } \\
\text { kencing, masuk angin, darah tinggi, } \\
\text { jantung. }\end{array}$ \\
\hline 5 . & $\begin{array}{l}\text { Ocimum } \\
\text { citriodorum }\end{array}$ & Daun & $\begin{array}{l}\text { Mencegah kemandulan, bau mulut } \\
\text { dan bau badan, menurunkan gula } \\
\text { darah, mengatasi epilepsi, mengatasi } \\
\text { perut kembung,arthtritis dan masuk } \\
\text { angin, mengobati batu ginjal }\end{array}$ \\
\hline 6. & $\begin{array}{l}\text { Coleus } \\
\text { atropurpureus }\end{array}$ & Daun & $\begin{array}{l}\text { Mengobati luks/borok, mengobati } \\
\text { bisul, ambeien, dan mengobati perut } \\
\text { kembung atau perut mulas }\end{array}$ \\
\hline 7. & $\begin{array}{l}\text { Orthosiphon } \\
\text { aristatus }\end{array}$ & $\begin{array}{l}\text { Daun, bunga, } \\
\text { biji, batang, } \\
\text { akar }\end{array}$ & $\begin{array}{l}\text { Batu ginjal, prostat, encok, masuk } \\
\text { angin, melancarkan pengeluaran air } \\
\text { kemih. }\end{array}$ \\
\hline 8. & Saraca & Bunga & $\begin{array}{l}\text { Mengobati luka memar, disentri, haid } \\
\text { tidak teratur, kram kaki, dan sebagai } \\
\text { antioksidan }\end{array}$ \\
\hline 9. & Ziziphus mauritiana & Daun, akar & $\begin{array}{l}\text { Mengobati gangguan pencernaan, } \\
\text { demam }\end{array}$ \\
\hline 10. & Euphorbia milli & $\begin{array}{l}\text { Daun, } \\
\text { batang, } \\
\text { bunga }\end{array}$ & $\begin{array}{l}\text { Mengobati hepatitis, pendarahan } \\
\text { rahim, luka bakar, dan mengobati } \\
\text { bisul }\end{array}$ \\
\hline
\end{tabular}




\begin{tabular}{|l|l|l|l|}
\hline 11. & Curcuma longa & Daun, umbi & $\begin{array}{l}\text { Meredakan rasa sakit saat menstruasi, } \\
\text { mengobati alzhaimer, mencegah } \\
\text { penyakit kanker, menjaga sistem } \\
\text { syaraf, asam lambung, menurunkan } \\
\text { berat badan, asam lambung }\end{array}$ \\
\hline 12. & $\begin{array}{l}\text { Peperomia } \\
\text { pellucida }\end{array}$ & Daun & $\begin{array}{l}\text { Mengobati luka bakar, bisul, jerawat, } \\
\text { sakit perut, asam urat }\end{array}$ \\
\hline 13. & Piper betle L & Daun & $\begin{array}{l}\text { Menghilangkan bau badan, mengobati } \\
\text { batuk, keputihan, membersihkan } \\
\text { mata, mengehntikan pendarahan, dan } \\
\text { obat hidung berdarah (mimisan). }\end{array}$ \\
\hline 14. & $\begin{array}{l}\text { Amaranthus } \\
\text { spinosus }\end{array}$ & $\begin{array}{l}\text { Seluruh } \\
\text { bagian } \\
\text { tumbuhan }\end{array}$ & $\begin{array}{l}\text { Mengatasi gangguan pernapasan, } \\
\text { bronkitis, susah buang air kecil, } \\
\text { kencing nanah, produksi asi lancer. }\end{array}$ \\
\hline 15. & $\begin{array}{l}\text { Andrographis } \\
\text { paniculata }\end{array}$ & Daun & $\begin{array}{l}\text { Menyembuhkan flu, membantu } \\
\text { mencegah penyakit jantung, } \\
\text { mencegah diabetes, menyembuhkan } \\
\text { infeksi, pencernaan, dan kolesterol. }\end{array}$ \\
\hline
\end{tabular}

Sumber: Hasil wawancara dengan masyarakat Kelurahan Sentosa, Azzamy 2016, Kartika T, 2017

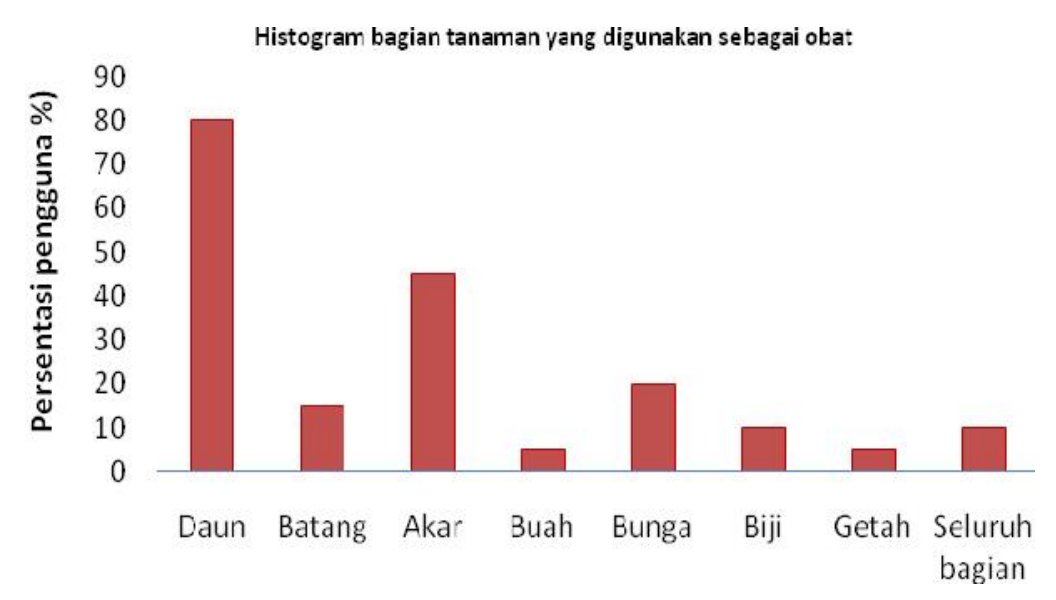

Gambar 1. Histogram bagian tumbuhan yang dimanfaatkan sebagai obat

Berdasarkan gambar 1. dibanding dengan bagian tumbuhan Pemanfaatan bagian tumbuhan sebagai obat tradisional yang banyak digunakan oleh masyarakat Kelurahan Sentosa yaitu pada daun dengan persentasi tertinggi sebesar $80 \%$, dan akar sebesar $45 \%$ lainnya.

Spesies tumbuhan obat dari class Dicotiledone yang diketahui di pekarangan rumah masyarakat Kelurahan Sentosa Kecamatan Seberang Ulu 2 Palembang dengan 
kegunaan yang berbeda-beda, spesies tumbuhan obat yang berhasil teridentifikasi sebanyak 15 spesies. Pada kelas dikotiledone bagian yang banyak digunakan sebagai obat adalah daun, karena pada daun banyak mengandung senyawa seperti tannin, alkaloid, minyak atsiri yang berguna sebagai obat yang tersimpan di jaringan pada daun. Khasiat daun berhubungan dengan pencernaan dan penggunaannya dapat direbus, dibuat ekstrak untuk dipoleskan pada tumbuh sebagai minyak atsiri dan dibuat minuman.

Pengobatan yang dilakukan dengan cara tradisional oleh masyarakat berkhasiat seperti daun beluntas memiliki bau yang khas aromatis dan rasanya getir serta menyegarkan. Berkhasiat untuk meningkatkan nafsu makan, membantu melancarkan pencernaan, meluruhkan keringat, menghilangkan bau badan dan bau mulut, meredakan demam, nyeri tulang, sakit pinggang, dan keputihan. Sedangkan akar beluntas mempunyai khasiat sebagai peluruh keringat dan penyejuk. Kandungan kimia di dalam beluntas berupa alkaloid, tannin, natrium, minyak atsiri, kalsium, flavonoida, magnesium, dan fosfor. Sedangkan akarnya mengandung flavonoida dan tannin. (Ardiansyah, 2002) .

Daun kenikir (Cosmos caudatus) mengandung saponin, flavonoid polifenol dan minyak atsiri. Akarnya mengandung hidroksieugenol dan koniferil alkohol. Daun kenikir banyak dikonsumsi masyarakat sebagai sayuran. Secara tradisional daun ini juga digunakan sebagai obat penambah nafsu makan, lemah lambung, penguat tulang (Pebriana et al. 2008).

Dalam tumbuhan euphorbia, terdapat kandungan senyawa berupa alkaliod isobubbialin dan epibubbialin. Kedua senyawa ini dapat mencegah penyakit liver, pendarahan rahim, luka bakar, bisul dan untuk melawan virus hepatitis B ( Sumarno, 2008).

Kandungan yang terdapat didalam tanaman bidara yaitu mengandung polifenol, triterpenoid, terpenoid, dan flavonoid. Kandungan fenolat pada tanaman bidara kaya akan manfaat biologis antara lain antioksidan, antiinflamasi, antimikroba, antifungi dan mencegah timbulnya tumor (Prior, 2003).

Dalam tumbuhan euphorbia, terdapat kandungan senyawa berupa alkaliod isobubbialin dan epibubbialin. senyawa ini dapat mengobati luka bakar, bisul, jerawat, sakit perut, membantu mengurangi asam urat.

Menurut Sisca Dharmayanti (2002), menyebutkan bahwa, kandungan minyak atsiri daun kemangi berkhasiat menyembuhkan diare, nyeri payudara, batu ginjal, gangguan pada vagina dan juga dapat mengatasi albuminuria.

Kandungan utama daun sambiloto laklton adrogra pholide (sat pahit), neoandrographolide dan nomoandrographolide, disamping itu daun sambiloto mengandung saponin, alkaloid, flavonoid dan kalmegin. Secara Farmakologis mempunyai sifat anti radang, anagesik, antiimflamasi, anti bakteri, anti malaria, hepatoprofektif, penawar racun, menstimulasi, menghambat sel tumor serta untuk mengobati penyakit hepatitis, radang 
paru, TBC paru, diare, kencing manis dan tipus abdominalis. (Nugroho,et.al.2016)).

Herba kumis kucing rasanya manis sedikit pahit, sifatnya sejuk. Berkhasiat sebagai antiradang, peluruh kencing (diuretik), menghilangkan panas dan lembap, serta menghancurkan batu saluran kencing (Dalimartha, 2001).

$$
\text { Mengkudu }
$$

(Morinda

citrifolia L.) untuk mengobati darah tinggi dan demam masuk angin.Contoh pemakaian dimasyarakat ambil satu buah mengkudu yang sudah masak di pohon, diperas airnya dan disaring dengan kain. Kemudian madu satu sendok makan dicampurkan air mengkudu tersebut, minumlah sebelum tidur $2 \mathrm{x}$ sehari untuk mengobati darah tinggi (Ibad, 2004).

\section{KESIMPULAN}

Dari hasil penelitian yang telah dilakukan di sekitar pekarangan Kelurahan Sentosa Kecamatan Seberang Ulu 2 Palembang dapat disimpulkan sebagai berikut:

1. Jenis tumbuhan berkhasiat obat yang ditemukan dipekarangan Kelurahan Sentosa Kecamatan Seberang Ulu 2 Palembang dari divisio Spermatopyta terdiri dari , 2 class, 13 familia, 14 ordo, 20 genus dan 20 spesies.

2. Bagian tanaman yang digunakan sebagai obat dari class Monokotiledone adalah rimpang seperti umbi/akar dan daun karena rimpang memiliki senyawa aktif, flavonoid, saponin, dan minyak atsiri, sedangkan class Docotiledone bagian yang banyak digunakan sebagai obat adalah daun, karena pada daun banyak mengandung senyawa seperti tannin, alkaloid, minyak atsiri yang berguna sebagai obat yang tersimpan di jaringan pada daun.

3. Pemanfaatan bagian tumbuhan berkhasiat obat persentasi tertinggi pada daun sebesar $80 \%$, sedangkan pada akar sebesar 45 $\%$.

\section{DAFTAR PUSTAKA}

Ardiansyah. (2002). Kajian Aktivitas Antimikroba

Ekstrak Daun Beluntas.

[Online] Tersedia:

https://repository.ipb.ac.id/h andle/123456789/6206.

Tesis.Institut Pertanian

Bogor 2002.Diakses 20 Juni 2019.

Azzamy. 2016. 250 Jenis Tanaman Obat Lengkap dengan Manfaat dan Khasiat. https://mitalom.com/250jenis-tanaman-obat-lengkapdengan-manfaat-dankhasiatnya-page-1/. Diakses $02-09-2019$.

Dalimartha, S., 2001, Atlas Tumbuhan Obat Indonesia, Jilid 2, Trubus Agriwidya, Jakarta

Dalimartha, S. (2009). Atlas tumbuhan obat Indonesia. (Edisi 6). Jakarta: Pustaka Bunda, Grup Puspa Swara Anggota IKAPI.

Deasy Anditasari K.H, Sri Kumalaningsih, Arie Febrianto Mulyadi.2014. Potensi Daun Suji (Pleomele Angustifolia) Sebagai Serbuk 


\begin{abstract}
PewarnaAlami (Kajian Konsentrasi Dekstrin Dan Putih Telur Terhadap Karakteristik Serbuk). Prosiding Seminar Nasional BKS PTN Barat : 1195-1202, 2014.
\end{abstract}

Dharmayanti, S. 2003. Berbagai Khasiat Daun Kemangi. http://www.

pikiran_rakyat.com/cetak/010

3/19/1003.htm . Diakses 24

Juni 2019.

Departemen Kesehatan RI. (2013). Suplemen III Farmakope Herbal Indonesia, Edisi I. Jakarta: Departemen Kesehatan RI.

Falah., Sayaktiningsih dan Noorcahyati. 2013. Keanekaragaman Jenis dan Pemanfaatan

\section{$T u$}

mbuhan Berkhasiat Obat oleh Masyarakat Sekitar Hutan Lindung Gunung Beratus Kalimantan Timur. Jurnal Penelitian dan Konservasi Alam. Vol.10 No.1. http://forda-mof.org. Diakses10 Juni 2019.

Gailea, R., 2004. Identifikasi Pemanfaatan Dan Pengembangan Tumbuhan Obat di Sekitar Taman Nasional Lore Lindu. Program Studi Pengelolaan Sumber Daya Alam Dan Lingkungan Sekolah Pasca Sarjana Institut Pertanian Bogor.

Hariana, A. 2008. Tumbuhan Obat dan Khasiatnya. Cetakan Kelima. Penebar Swadaya. Jakar

Herdiani, 2012. Potensi Tanaman
Obat Indonesia(online):

http://www.bbpp-

lembang.info/index.php/arsip/ artikel/artikel-pertanian/585-

potensi- tanaman-obatindonesia. Diakses tanggal 11 Juli 2019.

Ibad H.M.A.I. 2004. Keterampilan khusus di Bidang Pengobatan dan Perawatan Kecantikan Secara Tradisional. Hasil Karya Putra Nusantara. Jawa Tengah.

Kartika T.2017. Potensi Tumbuhan Liar Berkhasiat Obat di Sekitar Pekarangan Kelurahan Silaberanti Kecamatan Silaberanti. Jurnal Sainmatika FMIPA. Vol. 14. NO. 2. Desember 2017.

Nugroho A, Rahardianingtyas $E$, Putro W,B,D, Wianto.R.2016. Pengaruh Ekstrak Daun Sambiloto (Adrographis paniculata Ness.) terhadap Daya Bunuh Bakteri Leptospira Sp. ejournal.litbang.kemkes.go.id > index.php > MPK > article > .Diakses 2 September 2019.

Pebriana, RB., Wardhani, BWK., Widayanti, E., Wijayanti, NLS., Wijayanti, TR., Riyanto, S., Meiyanto, E., Pengaruh Ekstrak Metanolik Daun Kenikir (Cosmos caudatus Kunth.) Terhadap Pemacuan Apoptosis Sel Kanker Payudara, Pharmacon, Vol. 9, No. 1, Juni 2008.

Prior RL. 2003. Fruits and vegetables in the prevention of cellular oxidative damage. AmJ Clin Nutr, 78 (3): 570s-578s. 
Rahim., Kandowangko dan Uno. 2013. Identifikasi Tumbuhan Berkhasiat Obat yang Digunakan oleh Pengobatan Tradisional di Suku Bajo di Desa Torosiaje. Laporan Penelitian. Fakultas MIPA Universitas Negeri Gorontalo. http://journalscholar.google.ac. id.Diakses 17 Juli 2019.

Rahayu, S.E. 2002. Kaempferia galanga L. Kencur . Pusat Penelitian dan Pengembangan Tumbuhan Obat (P3TO) UNAS.

Rostiana, Ot ih dan. Dedi Soleh Effendi.2007. Teknologi Unggulan Kencur Perbenihan dan Budidaya Pendukung Varietas Unggul. Badan Penelitian Pengembangan Pertanian. Pusat Penelitian dan Pengembangan Perkebunan. ISBN: 978-979-8451-61-4. Bogor.

Rubiah, Djufri, Muhibbuddin. 2015. Kajian etnobotani tumbuhan obat penyakit kulit pada masyarakat Kabupaten Pidie.Jurnal Biologi Edukasi Edisi 14, Volume 7 Nomor 1, Juni2015, hal34.http://jurnal.unsyiah.a c.id/JBE. Diakses 6 Juli 2019.

RY Galingging, dalam bukunya, Bawang Dayak (Eleutherine palmifolia) sebagai Tanaman Obat Multifungsi Penerbit Warta Penelitian dan Pengembangan 15(3): 2-4, tahun 2009.

Shosan . Ethnobotanical Survey of Medicinal Plants Used in Curing Some Diseases in
Infants in Abeokuta South Local Government Area of Ogun State, Nigeria. American Journal of Plant Sciences. 2014. 